\title{
Formation Pore Pressure Variation of the Neocomian Sedimentary Succession (the Fahliyan Formation) in the Abadan Plain Basin, SW of Iran
}

\author{
Bahman Soleimani, ${ }^{1}$ Mohammad Hassani-Giv, ${ }^{1}$ and Iraj Abdollahi fard ${ }^{2}$ \\ ${ }^{1}$ Petroleum Geology, Shahid Chamran University of Ahvaz, Ahvaz, Iran \\ ${ }^{2}$ National Iranian Oil Company, Exploration Directorate, Tehran, Iran \\ Correspondence should be addressed to Bahman Soleimani; soleimani_b@scu.ac.ir
}

Received 16 June 2016; Revised 20 August 2016; Accepted 12 October 2016; Published 9 January 2017

Academic Editor: Mark Tingay

Copyright ( 2017 Bahman Soleimani et al. This is an open access article distributed under the Creative Commons Attribution License, which permits unrestricted use, distribution, and reproduction in any medium, provided the original work is properly cited.

\begin{abstract}
The Neocomian Fahliyan Formation is one of the important oil reservoirs in the Abadan Plain Basin, SW of Iran. To evaluate the pore pressure regime of the Fahliyan reservoir, 164 in situ pressure data points (MDT, XPT, and RFT) were analyzed from seven wells belonging to six oilfields. The pressure versus depth plot revealed that the Fahliyan reservoir is highly overpressured in all fields. The formation was characterized as a multilayered stacked reservoir with different pore pressure decreasing downward in a step-wise manner. Also, there is a major pressure step in the middle part of the reservoir, suggesting the presence of a regional efficient seal dividing the reservoir into two stacked compartments, where the upper compartment is more overpressured than the lower one. The stepped pressure pattern of the Fahliyan Formation is a regional phenomenon controlled by a factor governed regionally, the depositional condition, and facies lateral changes during the deposition of shallowing upward sequence of the Fahliyan reservoir. In addition, direct relationship is observed between the reservoir pressure and burial depth. This matter could amplify the initially generated overpressure state more possible due to dewatering of sediments and by-pass product of oil migration from Garau source rock to the Fahliyan reservoir.
\end{abstract}

\section{Introduction}

Sedimentary basins exhibit a variety of pore pressure distribution patterns. The distribution of pore pressure within a sedimentary basin may affect almost all processes and elements relevant to petroleum occurrence in sedimentary basins, including organic-matter maturation [1-3] and petroleum generation (e.g., [1, 4-13]). In addition, knowing the subsurface pressure of the sedimentary succession in a basin is very critical to select suitable mud weight for safe drilling, casing design, and preventing reservoir damage. Moreover, the detailed study of a reservoir pressure is necessary for field development.

Formation pore pressure in subsurface has been classified into normal pressure (equal to hydrostatic pressure), underpressure (less than hydrostatic pressure), and overpressure. Overpressure state in definition is an abnormal subsurface pressure in the formation pore pressure that is significantly higher than the hydrostatic pressure (e.g., $[14,15])$. Overpressure in sedimentary basins may be generated by two main groups of mechanisms (e.g., [16-18]): (1) stress applied to a compressible rock (disequilibrium compaction caused by poor fluid expulsion during compaction and tectonic compression) and (2) fluid expansion and/or increase in fluid volume, notably aquathermal pressuring, smectite to illite transformation, and organic-matter cracking induced fluid generation [19]. In addition, in some cases communication of sections due to faulting has been reported as the cause of the abnormal pressure in a shallow subsurface, like the case reported by Luo et al. [20], in Yinggehai basin, a Cenozoic rift basin on the NW margin of the South China Sea continental shelf.

A great number of sedimentological, stratigraphic, sequence stratigraphy, and facies/log based reservoir studies have 
been performed on the Lower Fahliyan carbonate reservoir (e.g., [21-27]) with limited number of investigations, carried out on the pressure regime and characterization in the Zagros Fold-Thrust Belt and the Abadan Plain Basin. Conclusions obtained from the Fahliyan time equivalent Yamama reservoir in the Iraqi Majnoon oil field represent that the Yamama reservoir is an overpressured segmented into at least two separate fault compartments [28]. The Fahliyan Formation is divided into the Berriasian-Valanginian, Lower Fahliyan which is the main reservoir, and the cyclic lagoonal to open marine Hauterivian, Upper Fahliyan [29]. Drilling experiences of the Fahliyan reservoir in the Abadan Plain Basin display a downward episodic overpressure events that may have been corresponded to the reservoir units within the sedimentary cycles. The aim of this study is to integrate available relevant data from the Fahliyan reservoir within the studied subcrop sections to evaluate the pressure regime and possible involved processes in the northern part of the Abadan Plain Basin, SW of Iran. To do this, first, the pressure characteristics of the Lower Fahliyan reservoir are evaluated qualitatively and quantitatively. Then, the pressure patterns are correlated stratigraphically between the different fields. Finally, all the possible involved processes are discussed.

\section{Geological Setting and Petroleum System of the Abadan Plain Basin}

The Zagros Fold/Thrust Belt (ZFTB) and its foreland basin are situated on the NE margin of the Arabian Plate. Beyond the Zagros frontal fault, the sedimentary cover is observed to have been barely affected by the Zagros folding. The Abadan Plain Basin is part of the Mesopotamian foredeep basin which is a narrow belt that extends from northern Iraq to the Persian Gulf ([30], Figure 1 in Pitman et al. [31] and in Abeed et al. [32]). The Abadan Plain Basin is located on the SW side of the Dezful Embayment in the SW of Iran (Figure 1). The Abadan Plain Basin and Dezful Embayment regions are separated based on differences in the structural trends. The border between the regions is defined by NW-SE trending gentle anticlines which are located along the SW margin of the Dezful Embayment [33]. The structures are without any outcrop, covered by a thickness of the recent alluvial sediment, and therefore only explored by geophysical data.

There are some N-S trending structures in the Arabian Plate known as the Arabian/Pan African trend. According to Al-Husseini [34], the generation age of the N-S trending structure in the Arabian Plate is reported 640-620 My (Precambrian time) as a result of the Amar collision. The most prominent N-S trending huge structure in the study area is the Azadegan paleohigh which is considered the northward extension of the Khurais-Burgan paleohigh in Kuwait and the Basrah/Zubair paleohigh in Iraq [34]. The Azadegan paleohigh is a basement-cored complex horst encompassing some of the oil fields in the area, such as Azadegan and Yadavaran [33]. Differential compaction affected by reactivation of structural lineaments is the main factor for generation of these huge structures. Therefore, the anticlines in the area are compactional type in view of Selley [11] classification. The compactional folds are irregularly shaped, reflecting the

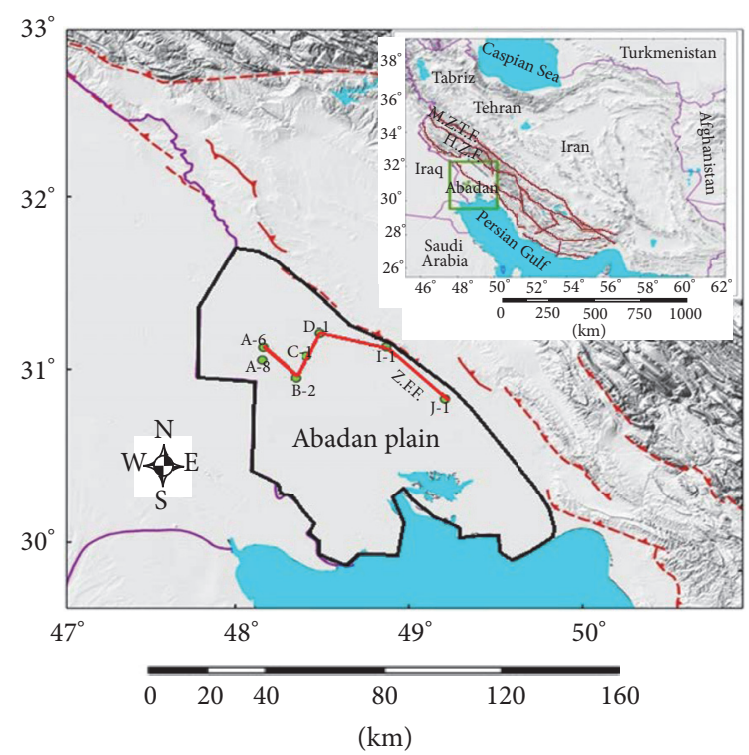

FIgURE 1: The location of studied wells on the map of the Abadan Plain Basin and contiguous area. The arbitrary line between wells A6, B-2, D-1, I-1, and J-1 corresponds to the stratigraphic correlation in Figure 6.

intersect of fault trends in the basement, whereas the compressional folds are generally elongated perpendicular to the axis of crustal shortening [11]. Also, compactional folds may have considerable variations in reservoir facies, across structure, the case which can clearly be observed in the Abadan Plain Basin [11]. The vertical closure in compactional folds is induced by the differential depositional rate and subsequent compaction between the crest and the flanks [11]. The Azadegan paleohigh has a profound effect on the sedimentary succession from reservoir geology point of view. The paleohigh experienced significant tectonic activity in the Early Cretaceous, leading to the deposition of the platform-type facies of the Fahliyan Formation on the shallow part and its basinal Garau counterpart. These two formations are time equivalent with interfingering relationship. From Early Cretaceous onward, the activation of this paleostructure has been reflected in the variation of the thickness and facies of the sedimentary succession. Proper juxtaposition of the petroleum system elements led to the accumulation of huge volume of oil in the area.

Oil to source rock correlation done by Abeed et al. [35] on the Iraqi neighboring fields suggests that the Upper JurassicLower Cretaceous Garau/Sulaiy and to some extent the Yamama carbonate rock units containing Type II-S kerogen are the effective source rocks. On the other hand, due to high level of maturity underlain by a disrupted Gotnia evaporate seal, the Sargelu Formation of Middle Jurassic does not appear to contribute to charging the Lower Cretaceous reservoirs [32, 35]. Oil generation from Upper Jurassic-Lower Cretaceous source rocks commenced in the Late Cretaceous in intrashelf basins and peak expulsion took place in the Late Miocene and Pliocene [31]. In the Abadan Plain Basin, the main reservoirs are Fahliyan, clastic part of Gadvan (Kushk sandstone member/Zubair Sandstone) and the basal Kazhdumi sandstone 


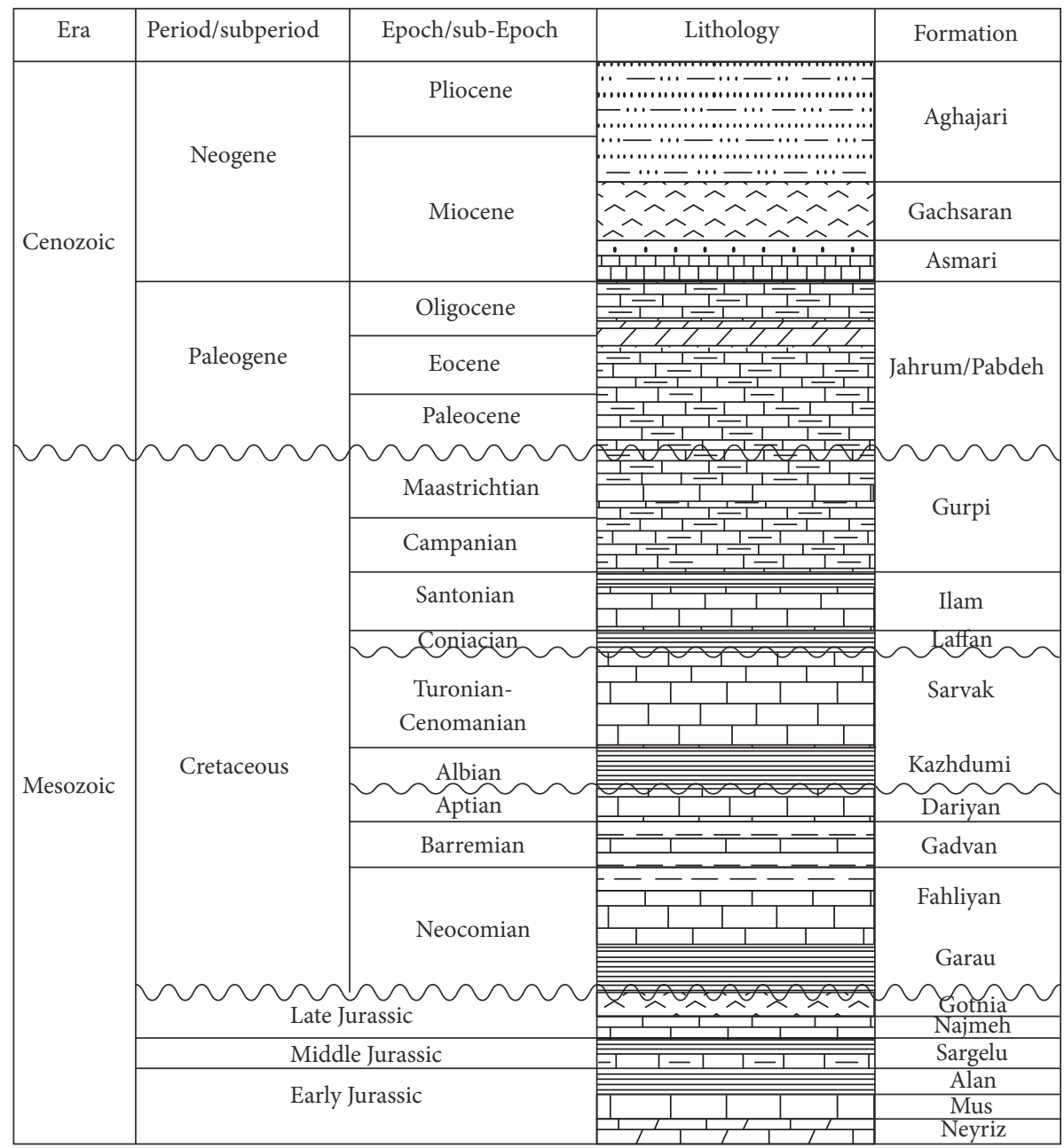

\begin{tabular}{|c|c|c|}
\hline$\therefore$ Sandstone & Sandy Marl & $E=$ Claystone \\
\hline 茞国 & 區 Limestone & Dolomitic limesto \\
\hline Evapo & hale & 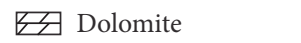 \\
\hline
\end{tabular}

FIGURE 2: The general penetrated stratigraphic column in the Abadan Plain Basin (no vertical scale).

(Azadegan sandstone member/Burgan sandstone), Sarvak, and Ilam formations. Furthermore, the reefal limestone of Tarbur in the middle of the Gurpi Formation (CampanianMaastrichtian) as well as the Asmari Formation is oil productive in some cases [36]. The main cap rock for the abovementioned reservoirs is mainly the argillaceous beds, overlying the reservoirs. The only evaporitic cap rock in this basin is the Gachsaran/Lower Fars Formation of Miocene age which seals the Asmari reservoir. We are facing a number of compartmentalized complex reservoirs both vertically and laterally in the Abadan Plain Basin, as a result of structural activity and subsequent depositional and postdepositional parameter interplay.

\section{Stratigraphy}

The general penetrated stratigraphic column in the Abadan Plain Basin is shown in Figure 2. As the focus of this study is on the Lower Cretaceous sediments, only the Fahliyan and Garau formations are described as follows.

3.1. Fahliyan Formation. The Fahliyan Formation (Neocomian age) has been divided into two parts based on lithofacies, namely, Upper Fahliyan and Lower Fahliyan. The Upper Fahliyan consists of an alternation of claystone and limestone, whereas the Lower Fahliyan mainly consists of limestone with minor claystone in the upper part.

3.2. Garau Formation. The Garau Formation (Neocomian age) consists of an alternation of shale and argillaceous limestone. The platform type Fahliyan and basinal Garau formations are time equivalent, with an interfingering relationship. The boundary with the underlying Gotnia Formation (Jurassic-Cretaceous boundary) is unconformable. 

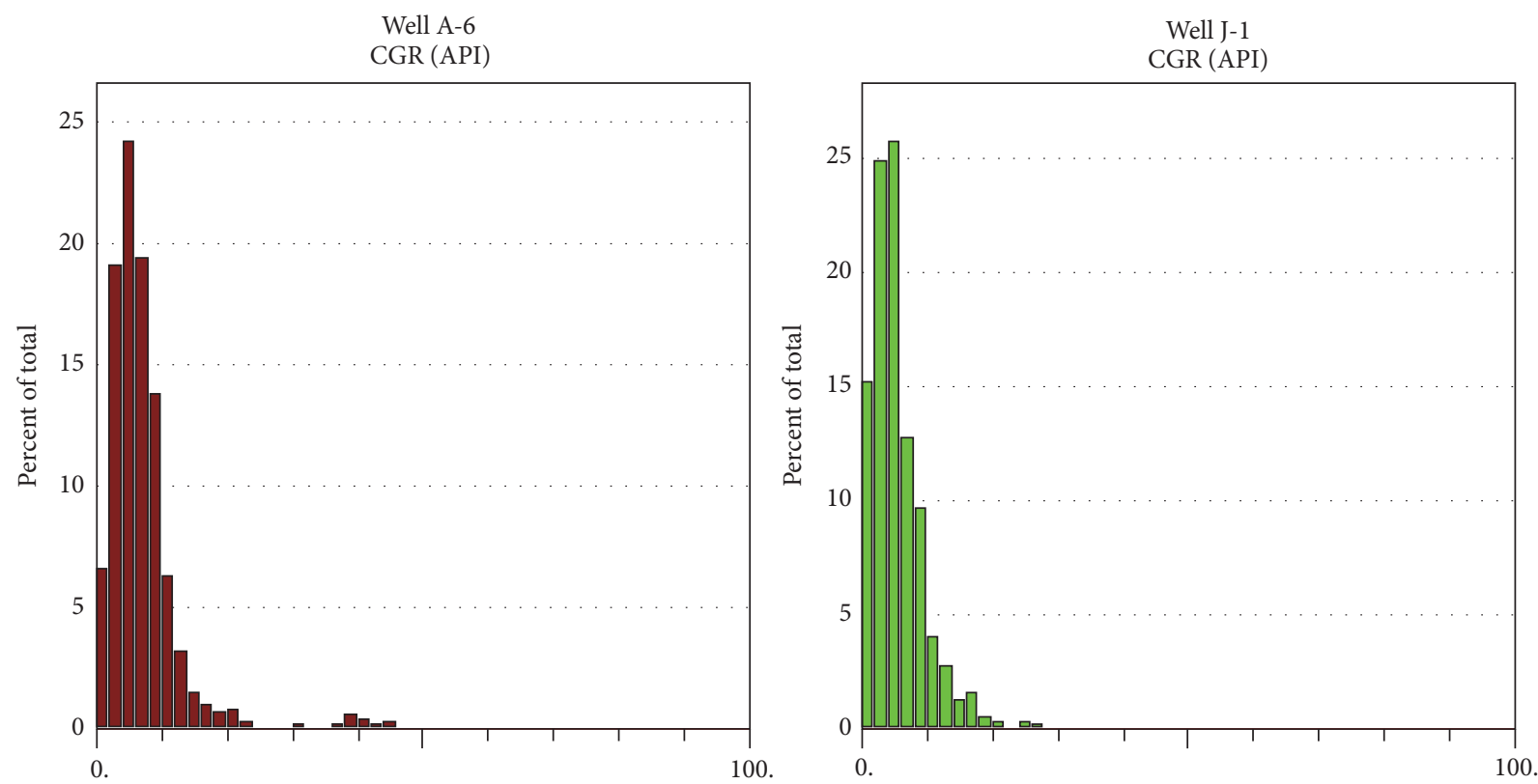

FIgURE 3: The CGR histogram (as the clay indicator) of Lower Fahliyan reservoir in wells A-6 and J-1. The value of the CGR is almost less than $20 \mathrm{API}^{\circ}$ suggesting a clay-free reservoir.

Following the flooding event of the earliest Cretaceous, the relative sea level gradually fell, resulting in deposition of a regressive shallowing upward Lower Cretaceous megasequence of the basinal Garau Formation to the Lower Fahliyan pure carbonate and then to the Upper Fahliyan/Ratawi Formation with an alternation of a carbonate and claystone resulting in more facies diversity, less lateral continuity, and finally thinner with limited extension porous intervals upward compared to the lower part of the reservoir [37, 38].

\section{Data Set}

The Upper Fahliyan is not a productive reservoir unit, so there are no in situ pressure measurements for this section, and they are not included in the study. The Rotary Table Elevation (RTE) varies from $11 \mathrm{~m}$ to $16 \mathrm{~m}$ and the air gap is $8 \mathrm{~m}$ for all the selected wells. The included wells in this study have full set log data (NGS, neutron, density, sonic, and resistivities logs) psi/ft except the Mio-Pliocene section with only gamma and in some cases sonic logs. The lithostratigraphy of all the included wells is very similar; therefore, we calculated the lithostatic gradient curve using the density log of well D-1. The average value of $0.96 \mathrm{psi} / \mathrm{ft}$ was obtained; so, we used the same general value of " 1 " $\mathrm{psi} / \mathrm{ft}$ ' for all wells. This information was then used to derive both lithostatic and hydrostatic pressure gradients. The Repeat Formation Tester (RFT), Modular Dynamic formation Tester (MDT), and Formation Pressure Test $\log (\mathrm{XPT})$ run into borehole to measure in situ reservoir pore pressure and mobility as well as collecting reservoir fluid (in the case of MDT) were used to determine fluid densities and fluid contacts. To evaluate the pore pressure characteristics and pressure regime of the Lower Fahliyan reservoir, a total number of 164 in situ pore pressure measurements
TABLE 1: The list of used in situ pressure data points for each well.

\begin{tabular}{lcccc}
\hline Field & $\begin{array}{c}\text { Well } \\
\text { number }\end{array}$ & Tool & $\begin{array}{c}\text { Number of } \\
\text { measurements }\end{array}$ & Drilling fluid \\
\hline A & 6 & RFT & 32 & Oil based mud \\
A & 8 & RFT & 37 & Water based mud \\
B & 2 & RFT & 35 & Oil based mud \\
C & 1 & XPT & 24 & Oil based mud \\
D & 1 & MDT & 14 & Oil based mud \\
I & 1 & XPT & 6 & Oil based mud \\
J & 1 & XPT & 16 & Oil based mud \\
\hline
\end{tabular}

(RFT, XPT, and MDT data points) belonging to seven wells from six different fields (see Figure 1 for location) have been analyzed in this study. The outliers such as dry test (large drawdown and very slow or no build-up), lost seal (failure of packer seal and communication to hydrostatic pressure), and supercharged data were eliminated from the main data set (Table 1). To confirm depositional changes and find some lithological information through the Fahliyan reservoir, selected samples were analyzed by XRF method as well. These data can be applied to chem-stratigraphy analysis.

\section{The Pressure Regime of the Fahliyan Reservoir}

The Lower Fahliyan/Yamama reservoir consists of carbonate with low clay content (Figure 3) deposited in a ramp-type platform during Neocomian time ([22,39,40]). The pressure versus depth plot (Figure 4) reveals that the Fahliyan reservoir is highly overpressured, about one and half times 


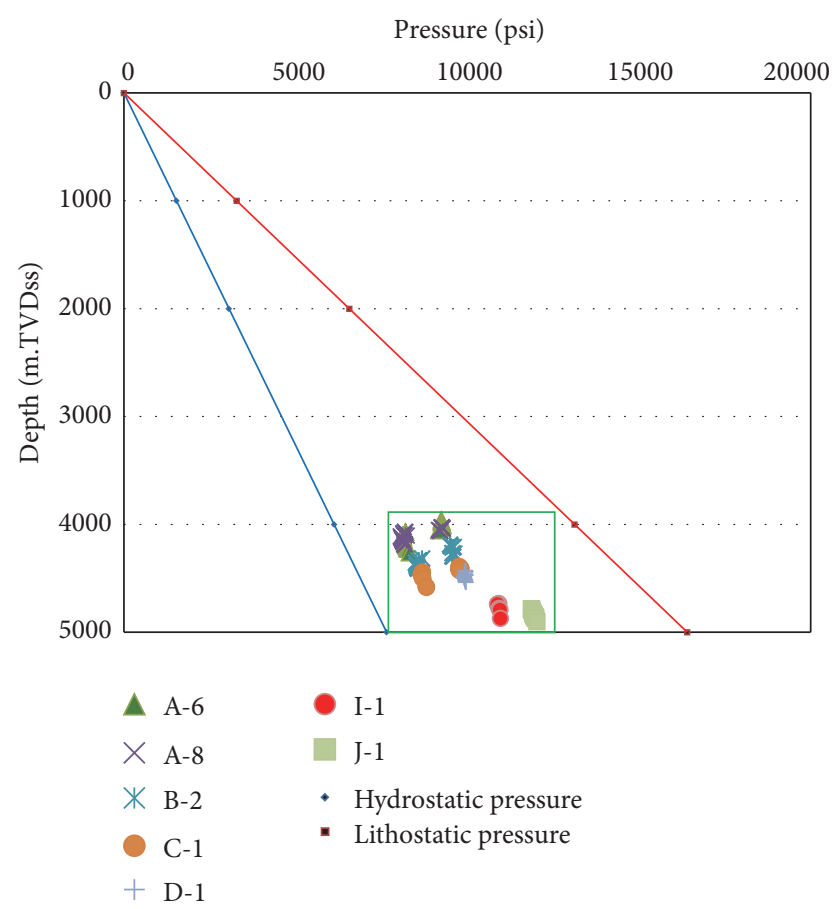

FIgURE 4: The pressure versus depth plot of the Lower Fahliyan reservoir. The red line is lithostatic pressure gradient ( $1 \mathrm{psi} / \mathrm{ft})$; the blue line is hydrostatic pressure gradient $(0.46 \mathrm{psi} / \mathrm{ft})$. The measured pressure data from seven wells plotted between these two lines indicating overpressuring of the Fahliyan reservoir in all seven different wells. The area inside the square denotes a zoomed-in version, Figure 5.

of hydrostatic pressure (Table 2) in all the six studied fields. Moreover, as the plot (Figure 5) shows it is a multilayered stacked reservoir with different pressure decreasing downward in a step-wise unexpected manner in all studied fields (Figures 4 and 5). A similar step-wise decreasing downward has been reported from the Yamama reservoir in the Iraqi Majnoon oil field [28]. The stair-step pattern of pore pressure is a characteristic of multiple-stacked pressure compartments [41].

The reservoir includes an alternation of porous strata as reservoir layers separated by thin low porosity and impermeable ones (Figure 6). Each layer has its own pressure characteristic with a pressure trend approximately parallel to the stacked overlying and underlying reservoir intervals. The deeper layers show a pressure decrease gradually in a stepwise pattern (Figures 4 and 5). The value of pore pressure drop between two layers separated by a seal is about 50 100 psi. It is noteworthy that, in the middle of the reservoir column, the plot shows a remarkable drop in pressure in all six studied fields. The value of pressure drop ranged from 909 psi in well B-2 to 1084 psi in well C-1. Detailed sequencewise stratigraphic correlation revealed that the major pore pressure step coincides with the strata, stratigraphically correlatable between the studied fields, suggesting a geological process as the controlling parameter (Figure 6). Among the oil bearing layers there is one or two water prone intervals in wells B-2 and C-1 coinciding above the major pressure step.

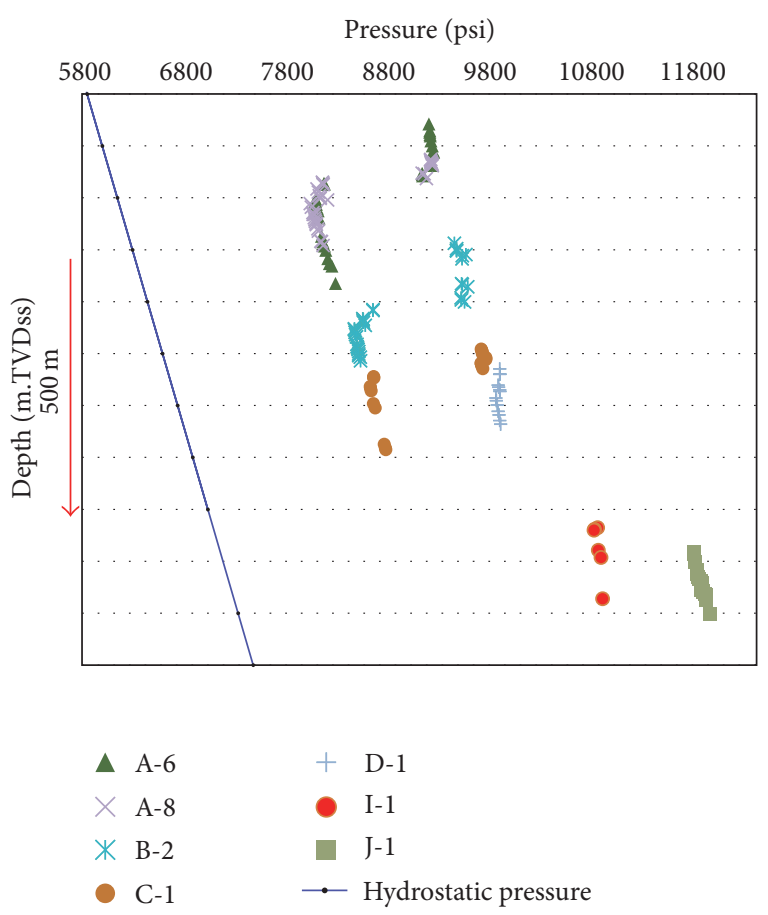

Figure 5: The pressure versus depth plot of the Lower Fahliyan reservoir from six different fields, zoomed in from Figure 4, showing a multilayered stacked reservoir with different pressures. The reservoir pressure decreases downward in a step-wise pattern. Also, the main pressure step can be seen clearly in wells A-6, A-8 (field A), B-2 (field B), and C-1 (field C) but not in wells D-1 (field D), I-1 (field I), and J-1 (field J) due to facies change of Fahliyan to Garau. The main pressure step suggests the presence of a regional efficient seal dividing the Lower Fahliyan reservoir into two stacked compartments. The pressure trend of the sublayers of each compartment in different fields shows more or less a similar trend. The hydrostatic pressure (blue line) has been attached as a reference line.

A detailed stratigraphic correlation revealed that the similar time equivalent strata have approximately similar pore pressure trend in different fields, as if they are supported by a unique aquifer. In well D-1, three separated overpressured layers exist, but less overpressured compartment below the regional main step does not exist, due to reservoir facies change of platform Fahliyan Formation to a nonreservoir basinal Garau Formation. Distancing eastward from the crest of the basement-cored Azadegan paleohigh due to paleodepositional environment, the base of the clay-free porous carbonate facies of the Fahliyan Formation changes to a nonreservoir basinal lime mud of the Garau Formation (Figure 6). The Fahliyan reservoir is an overpressured one, but it is not observed to be multilayer in wells I-1 and J-1 due to absence of interbedding efficient seals in these two wells. Containing a continuous porous interval without remarkable impermeable sections, in the oil column, the reservoir in these two I and J fields is more homogenous compared to the wells in A, B, C, and D fields (Figure 6).

Several parameters have been used to characterize the overpressure magnitude including excess pressures (pore 


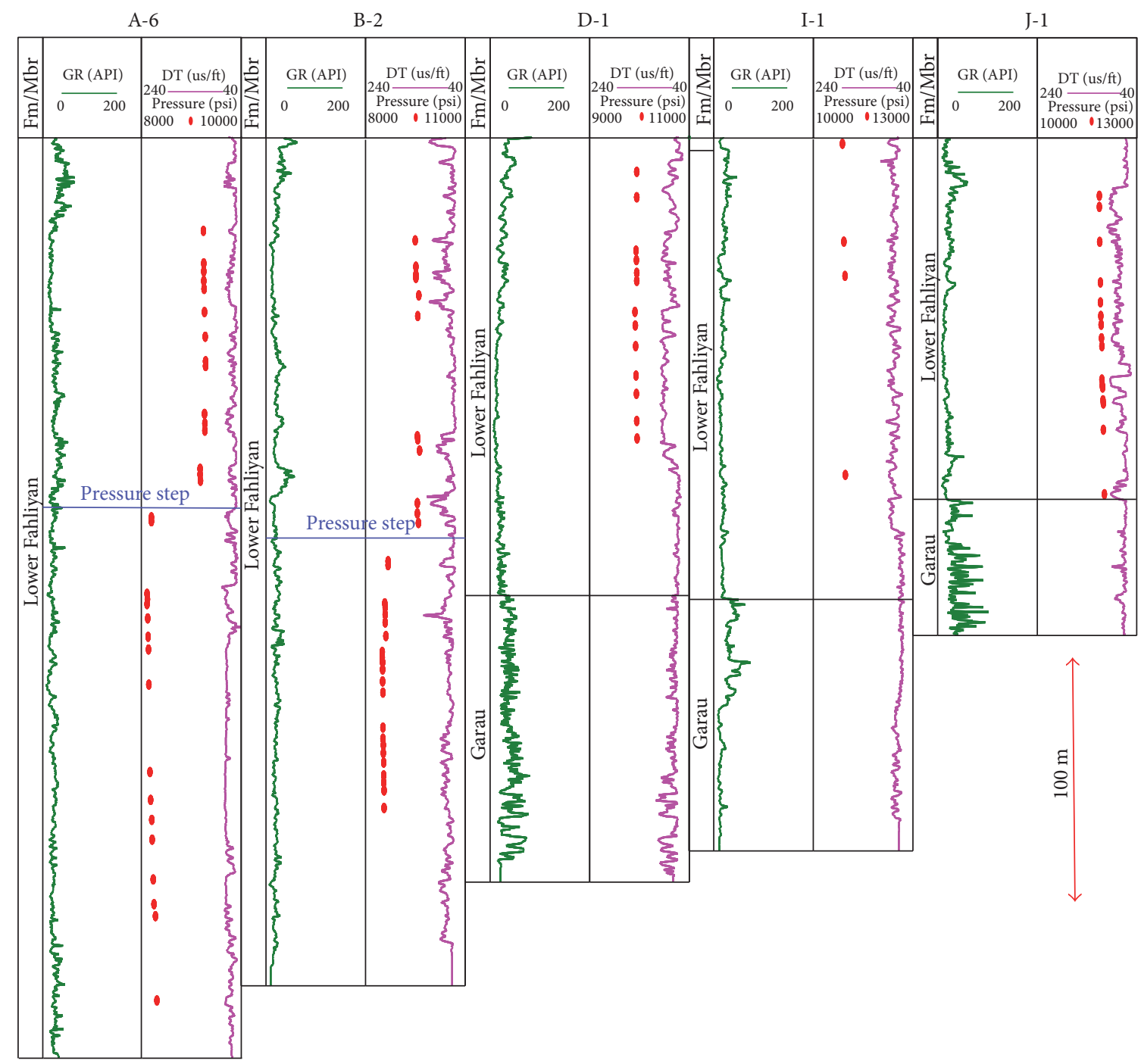

FIGURE 6: Shown is the stratigraphic correlation chart of the Lower Fahliyan Formation in an overall west-east direction (left to right) through wells A-6, B-2, D-1, I-1, and J-1. The green curve is gamma ray, the pink is sonic travel time, and the red points are the pressure data plotted against the wireline logs. The blue line shows the stratigraphic position of the regional seal (main pressure step) in A-6 and B-2 wells, separating the upper and lower compartments. Also, the step-wise pressure pattern can be seen in each compartment. The stratigraphic position of the regional seal is correlatable through fields A and B. The equivalent strata of lower compartment (below the main pressure step) change facies to nonreservoir Garau Formation in wells D-1, I-1, and J-1.

pressure minus hydrostatic pressure at equivalent depth, $\Delta P$ ), pressure coefficients (the ratio between pore pressure and the hydrostatic pressure), and the overpressure ratio (the ratio between pore pressure and vertical stress) [42] (Table 2). Each porous interval with different pressure values, enclosed between two low porosity layers, has been defined as a zone. The zones with similar numbers are not age-equivalent in different wells. The hydrostatic pressure was computed based on the $0.465 \mathrm{psi} / \mathrm{ft}$ [11]. The excess pressure $(\Delta P)$ decreases from the upper reservoir layers downward ranged from 1842.8 psi in well A- 8 to 3746 in well I- 1 . The $P_{p} / P_{h}$ ratio varies between 1.64 in well J-1 and 1.28 in well C-1 (Z-4, Z-5). The $P_{p} / S_{v}$ ratio ranges between 0.7 in well J-1 and 0.55 in wells A-8 (Z-5), B-2 (Z-6), and C-1 (Z-3 and Z-4).

\section{Discussion}

The pressure data suggest that the Fahliyan Formation, similar to the Yamama reservoir in Majnoon field in SE of Iraq, is an overpressured multilayer reservoir [28]. There are two main compartments vertically separated by a dense limestone that acts as an efficient seal, where the upper compartment is significantly more overpressured than the lower one. The stratigraphic position of the major pressure step coincides with the strata correlatable regionally in view point of sequence stratigraphy.

The pore pressure regime of the Fahliyan reservoir can be discussed from two different viewpoints: the probable causes of overpressuring and more importantly the reason for vertical compartmentalization and the specific step-wise pressure 
TABLE 2: Pressure characteristics of the Fahliyan reservoir layers of the fields under study. The zones with similar numbers are not ageequivalent strata.

\begin{tabular}{|c|c|c|c|c|c|c|c|c|}
\hline Field & Zone & Depth (m) & $\begin{array}{c}\text { Pore } \\
\text { pressure } \\
\left(P_{p}\right)\end{array}$ & $\begin{array}{c}\text { Hydrostatic } \\
\text { pressure (psi) }\end{array}$ & $\begin{array}{l}\text { Excess } \\
\text { pressure } \\
\Delta P(\mathrm{psi})\end{array}$ & $\begin{array}{l}\text { Vertical } \\
\text { stress, } S_{v} \\
\quad(\mathrm{psi})\end{array}$ & $\begin{array}{c}\text { Pressure } \\
\text { coefficient } \\
\left(P_{p} / P_{h}\right)\end{array}$ & $\begin{array}{l}\text { Overpressure } \\
\text { ratio }\left(P_{p} / S_{v}\right)\end{array}$ \\
\hline \multirow{7}{*}{ A-6 } & 1 & $\times 972$ & 9245.8 & 5994.8 & 3251.0 & 13032.1 & 1.54 & 0.71 \\
\hline & 2 & $\times 014$ & 9279.9 & 6058.2 & 3221.7 & 13169.9 & 1.53 & 0.70 \\
\hline & 3 & $\times 045$ & 9268.7 & 6105.0 & 3163.7 & 13271.6 & 1.52 & 0.70 \\
\hline & 4 & $\times 067$ & 9177.7 & 6138.2 & 3039.5 & 13343.8 & 1.50 & 0.69 \\
\hline & 5 & $\times 086.2$ & 8203 & 6167.1 & 2035.9 & 13406.8 & 1.33 & 0.61 \\
\hline & 6 & $\times 117$ & 8119.9 & 6213.6 & 1906.3 & 13507.9 & 1.31 & 0.60 \\
\hline & 7 & $\times 134$ & 8136.7 & 6239.3 & 1897.4 & 13563.7 & 1.30 & 0.60 \\
\hline \multirow{5}{*}{ A- 8} & 1 & $\times 039$ & 9263.6 & 6095.9 & 3167.7 & 13252.0 & 1.52 & 0.70 \\
\hline & 2 & $\times 065.3$ & 9178.17 & 6135.6 & 3042.6 & 13338.2 & 1.50 & 0.69 \\
\hline & 3 & $\times 083$ & 8187.5 & 6162.3 & 2025.2 & 13396.3 & 1.33 & 0.61 \\
\hline & 4 & $\times 096$ & 8134.45 & 6181.9 & 1952.5 & 13439.0 & 1.32 & 0.61 \\
\hline & 5 & $\times 124$ & 8067 & 6224.2 & 1842.8 & 13530.8 & 1.30 & 0.60 \\
\hline \multirow{6}{*}{ B-2 } & 1 & $\times 198.5$ & 9498.4 & 6336.6 & 3161.8 & 13775.3 & 1.50 & 0.69 \\
\hline & 2 & $\times 276.5$ & 9569.8 & 6454.4 & 3115.4 & 14031.2 & 1.48 & 0.68 \\
\hline & 3 & $\times 303.5$ & 9564.8 & 6495.1 & 3069.7 & 14119.8 & 1.47 & 0.68 \\
\hline & 4 & $\times 326.5$ & 8688.7 & 6529.8 & 2158.9 & 14195.2 & 1.33 & 0.61 \\
\hline & 5 & $\times 343.5$ & 8587.9 & 6555.5 & 2032.4 & 14251.0 & 1.31 & 0.60 \\
\hline & 6 & $\times 363$ & 8505.8 & 6584.9 & 1920.9 & 14315.0 & 1.29 & 0.59 \\
\hline \multirow{5}{*}{ C-1 } & 1 & $\times 411$ & 9766.1 & 6657.3 & 3108.8 & 14472.5 & 1.47 & 0.67 \\
\hline & 2 & $\times 437.7$ & 9762.5 & 6697.6 & 3064.9 & 14560.1 & 1.46 & 0.67 \\
\hline & 3 & $\times 464$ & 8696.2 & 6737.3 & 1958.9 & 14646.4 & 1.29 & 0.59 \\
\hline & 4 & $\times 483$ & 8662.47 & 6766.0 & 1896.5 & 14708.7 & 1.28 & 0.59 \\
\hline & 5 & $\times 516$ & 8694 & 6815.8 & 1878.2 & 14817.0 & 1.28 & 0.59 \\
\hline \multirow{3}{*}{ D-1 } & 1 & $\times 443.5$ & 9949.5 & 6706.4 & 3243.1 & 14579.1 & 1.48 & 0.68 \\
\hline & 2 & $\times 475$ & 9933.8 & 6753.9 & 3179.9 & 14682.5 & 1.47 & 0.68 \\
\hline & 3 & $\times 499.5$ & 9910.9 & 6790.9 & 3120.0 & 14762.9 & 1.46 & 0.67 \\
\hline $\mathrm{I}-1$ & L.Fa & $\times 754.5$ & 14240.7 & 7175.8 & 7064.9 & 15599.5 & 1.98 & 0.91 \\
\hline $\mathrm{J}-1$ & L.Fa & $\times 797.7$ & 11873.07 & 7241.0 & 4632.1 & 15741.3 & 1.64 & 0.75 \\
\hline
\end{tabular}

pattern. Kerogen to gas maturation is a commonly hypothesized mechanism for the generation of overpressuring. Although the burial depth of the Fahliyan reservoir is enough for kerogen maturity, because of the low clay content (Figure 3) and the negligible amount of organic matter in the Fahliyan reservoir itself, organic cracking most likely could not be considered as an efficient overpressuring mechanism in the Fahliyan reservoir. The buoyancy effect results from the density difference of water and oil, which is related to the height above OWC. Among the studied wells, the highest value of overpressure generated by the buoyancy effect for an oil column of $145 \mathrm{~m}$ with the oil pressure gradient of $0.36 \mathrm{psi} / \mathrm{ft}$ is calculated to be $52 \mathrm{psi}$. Also, the pressure generated by the buoyancy in Lower Fahliyan reservoir of Darquain Field in the Abadan Plain Basin (not included in this study) has been computed as 90 psi, for an oil column of $250 \mathrm{~m}$ [43]. Therefore, buoyancy pressure variation cannot explain the pressure pattern of the Lower Fahliyan reservoir.
However, dewatering and also kerogen cracking of the Garau Formation as the regional source rock which interfingered with Fahliyan during burial could reveal a huge volume of water and also hydrocarbon, squeezed upward and in a lateral way to the carbonate layers of the Fahliyan Formation. Thus, this phenomenon can be considered as an overpressuring mechanism in the Fahliyan reservoir if the pore system was confined.

The crossplot of pore pressure versus depth (Figure 7) shows a direct relationship between the pore pressure and burial depth, so that, with increasing burial depth, pore pressure increases with a nonlinear trend. The uppermost pressure measurements in the Lower Fahliyan reservoir have been selected in each well. At shallower depth the pressure increase seems close to linear, but, at burial depth of more than $4700 \mathrm{~m}$, pore pressure increases significantly probably due to fully compacting pore throats of porosity system resulting in permeability decrease and preventing escape of fluids from 


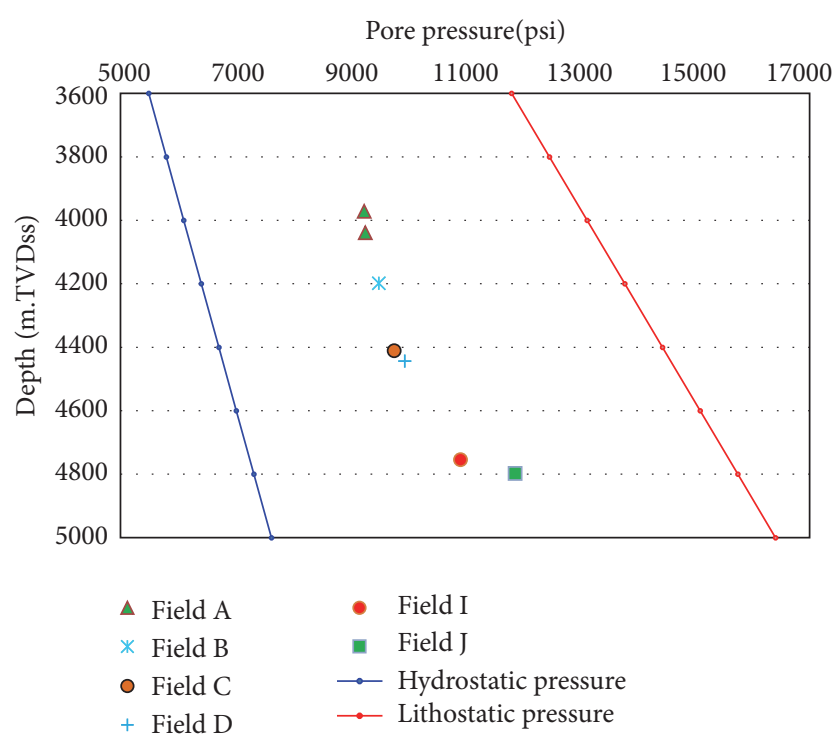

FIGURE 7: The reservoir pressure versus depth in all six different fields. The uppermost pressure measurements in the Lower Fahliyan reservoir have been selected in each well.

pore spaces. The pore pressure/reservoir burial depth ratio varies from 2.2 in C and D fields to 2.5 in J field. To assess the role of burial depth in overpressuring, the burial history plot (Figure 8) was done for wells B-2, D-1, and J-1.

There are two main rapid sedimentation periods in sedimentary succession of middle Cretaceous onward, the first occurred from 99.6 My to 89.3 My (Cenomanian-Turonian), and the latter occurred from $15.98 \mathrm{My}$ to the present day. The calculated rates of sedimentation for the CenomanianTuronian period in wells B-2, D-1, and $\mathrm{J}-1$ are about 66.21 M/My, 70 M/My, and $81.26 \mathrm{M} / \mathrm{My}$, respectively. The calculated sedimentation rates for the Mio-Pliocene period in wells B-2, D-1, and J-1 are about 104.57 M/My, 132.12 M/My, and $142.83 \mathrm{M} / \mathrm{My}$, respectively. The Mio-Pliocene sedimentary succession has been deposited with a high sedimentation rate, following the Zagros folding. Regarding overpressure mechanisms, disequilibrium compaction accounts for overpressuring usually in unconsolidated sedimentary succession $[17,44,45]$. Although the disequilibrium compaction cannot be considered as the main cause in this case, the high sedimentation rate of Mio-Pliocene could amplify the initially generated overpressuring.

One of the possible reasons for the specific pressure distribution and pattern may be due to different oil composition of different layers, in terms of API gravity and GOR. Different oil compositions lead to different fluid densities which could lead to different hydrocarbon buoyancy values. To assess the possible role of oil composition in pressure pattern of the Fahliyan reservoir, the hydrocarbon components, obtained from PVT analyses in well A-6, were plotted on star diagrams (Figure 9). To prevent masking effect of $\mathrm{C}_{1}$ on the other components oil composition was plotted with and without the $\mathrm{C}_{1}$ component. As the plot shows, a close similarity can be seen between the compositions of oil in different layers in one compartment and also between two stacked compartments suggesting that the different hydrocarbon composition may not be considered as the cause for this pressure pattern. In addition, the aquifer zones (based on the test results), zones 3,4 , and 5 in well A-8, follow the stepped pressure pattern of oil zones too (Figure 10).

There is no pressure communication between various sublayers through the oil column. Therefore, connection with the deeper horizons due to faulting could not be considered as the overpressuring mechanisms in the area. Analyzing the pressure data suggests a pressure communication between the time equivalent reservoir layers of wells A-6 and A-8. Despite this, the oil/water contact (OWC) in well A-6 is about $120 \mathrm{~m}$ deeper compared to well A-8. This phenomenon initially may be interpreted as the presence of a fault which is segmenting the reservoir into two adjacent compartments, like the case reported by Chatterjee et al. [28] in the Iraqi neighboring Majnoon oil field or as tilted OWC as a result of a hydrodynamic flow in aquifer, such as in the western flank of Majnoon field where the OWC is about $120 \mathrm{~m}$ deeper than the eastern flank, attributed to the presence of a west dipping normal fault. Based on the acoustic impedance profile (Figure 11) the OWC in well A-6 was controlled by a local sedimentary feature (clinoform) formed in the position of shelf-edge. As Figure 11 shows, the top of the clinoform geometry does not follow the top of the Lower Fahliyan, then causing a local stratigraphic-induced vertical closure in the position of well A-6. This suggests a complex, structural-stratigraphy hydrocarbon trap at least for some of the Fahliyan reservoir layers.

With the presence of the efficient regional seal, oil from the lower compartment could not vertically charge the upper compartment. Therefore, the lateral migration might be the effective process at least for charging the upper compartment. After spilling the lower compartment the oil could migrate laterally, probably to a long distance, then, crossing the top seal through weak zones such as structural lineaments, and finally charging the upper compartment. It is noteworthy that all the Cretaceous and Tertiary reservoirs in the area have the oil sourced from Garau/Sargelu [31, 46]. As mentioned, the wells belong to different fields which appear to have similar pressure variation patterns, suggesting that it is a regional phenomenon, probably regional patterns of sedimentation, control spatial distribution, and lateral continuity of depositional facies. Compacting of such a pile of reservoir layers could result in a stepped type present pore pressure pattern.

The chemical variation plots of selected major elements (Figure 12) were plotted in two drilled wells. These plots are showing depositional changes with increasing depths. Chemical oxides of $\mathrm{SiO}_{2}, \mathrm{Al}_{2} \mathrm{O}_{3}, \mathrm{Fe}_{2} \mathrm{O}_{3} \mathrm{CaO}$, and $\mathrm{SO}_{3}$ oxides are indicating clear trends to depth. It is a general assumption that the three former oxides can be related to detritus material while $\mathrm{CaO}$ and $\mathrm{SO}_{3}$ are related to the chemical deposition in the basin (during Neocomian period of Fahliyan Formation). As a result, zones with high $\mathrm{Al}_{2} \mathrm{O}_{3}$ and $\mathrm{SiO}_{2}$ resemble increasing shale values acting as a seal between two parts.

By comparing to pore pressure data in all oil fields, a marked horizon can be identified as a separation layer between higher formation pore pressure (upper part) and lower pore pressure (lower part). This index layer is around $4210 \mathrm{~m}$ in well B-2 and $4455 \mathrm{~m}$ in well C-1. However this 

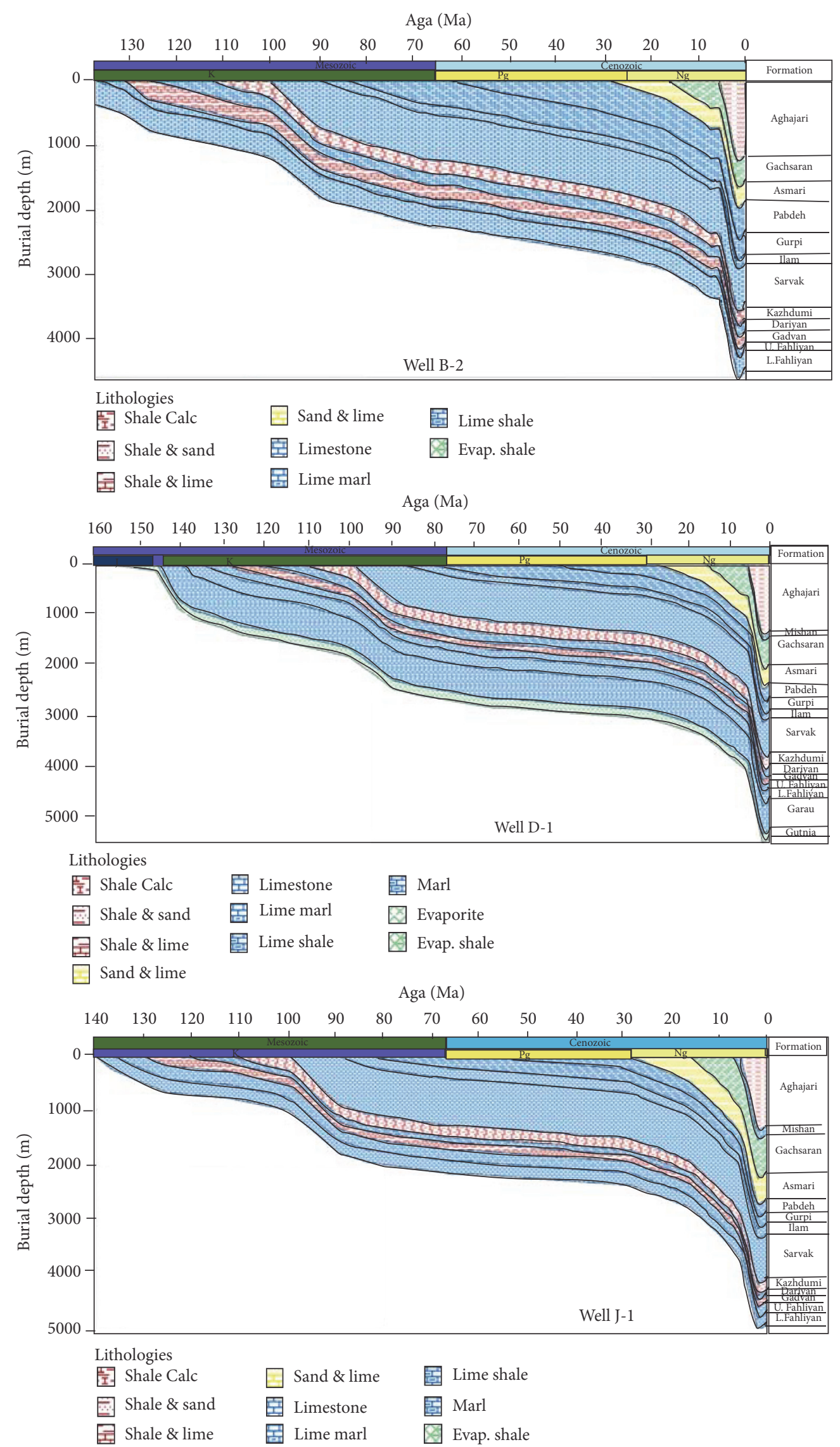

FIGURE 8: Burial history model for wells B-2, D-1, and J-1. There are two main breaks in depositional rate in all three wells, the first occurred from 99.6 My to 89.3 My (during Cenomanian-Turonian), and the more important second one occurred from 15.97 My to the present day. 


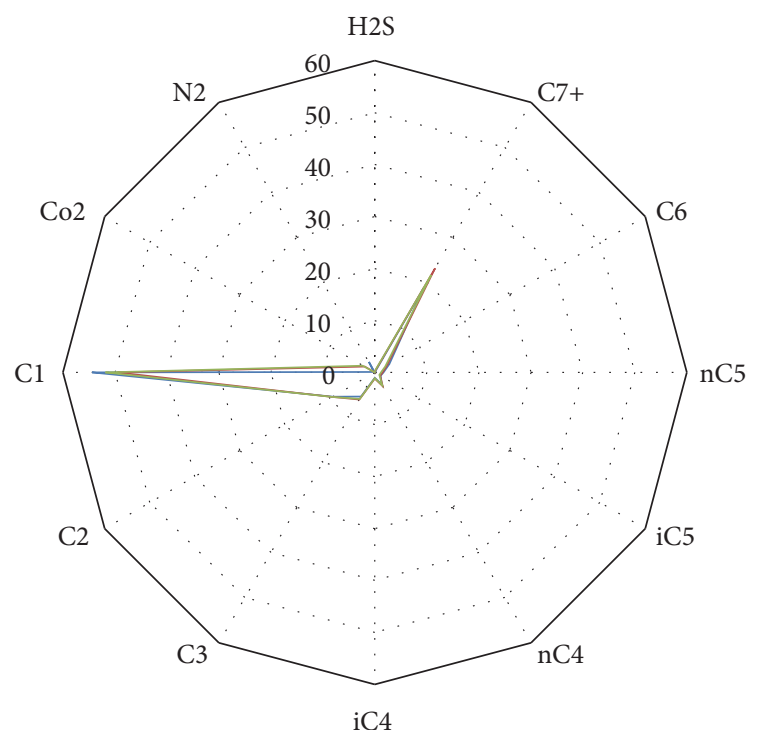

A-6, Z-1 (U.compartment)

A-6, Z-3 (U.compartment)

— A-6, Z-5 (L.compartment)

(a)

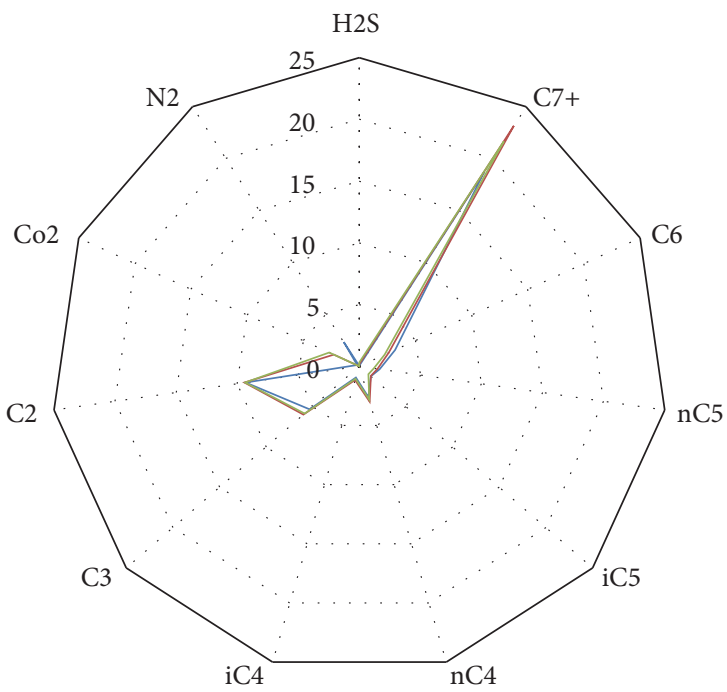

A-6, Z-1 (U.compartment)
A-6, Z-3 (U.compartment)
A-6, Z-5 (L.compartment)

(b)

FIGURE 9: The oil composition (obtained from PVT analysis) of upper (U.) and lower (L.) compartments, in well A-6, (a) with C1 and (b) without $\mathrm{C} 1$ component.

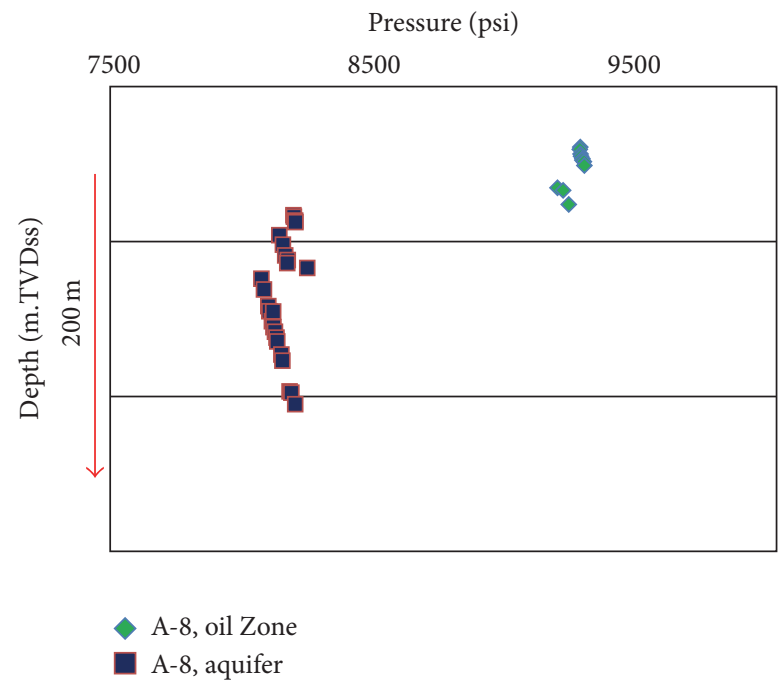

Figure 10: Reservoir pressure versus depth in well A-8. The green points are from oil zone and the blue points are from water zone (based on the test results). The step-stair pressure pattern can be seen in both oil and water zones.

layer can be varied in different locations. It seems this pattern is attributed to lithological variations and, therefore, the pore pressure behaviors of these two parts are different. The authors propose they are different reservoirs with their characteristics. The pressure decreasing pattern in each section can be due to increasing of detrital particles by increasing of depth and permitting decreasing the pore pressure.

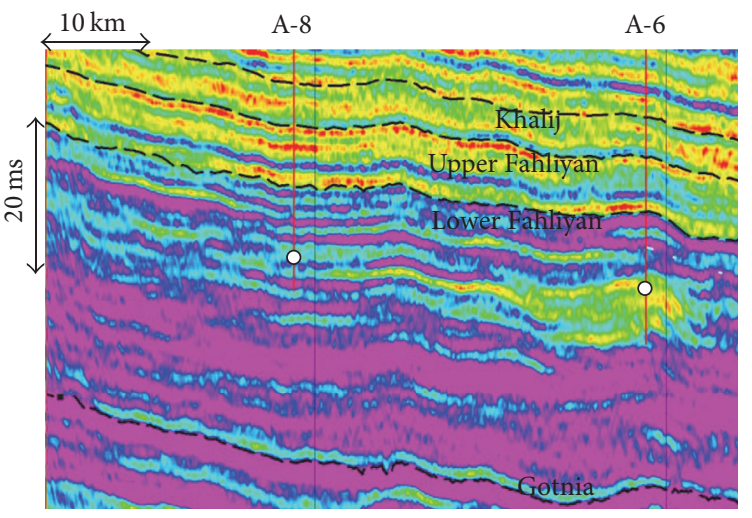

Figure 11: The inverted seismic section showing the clinoform sedimentary feature, forming a local vertical closure, hence, controls oil/water contact (OWC) in well A-6. The white circles indicate the OWC in wells A-8 and A-6.

\section{Conclusion and Results}

Evaluating a total number of 164 in situ reservoir pressure data points from six different fields revealed that the Fahliyan/Yamama in the Abadan Plain Basin, SW Iran, is an overpressured multilayered stacked reservoir, with two main vertically stacked compartments separated by a low permeable dense carbonate as an efficient regional seal. The upper compartment is more overpressured, about 900 to $1000 \mathrm{psi}$ more than the lower one. In each compartment the pressure decreased in a step-stair pattern both in oil and in water bearing zones. Considering the remarkable different pressure between two compartments, there should be two OWC, 


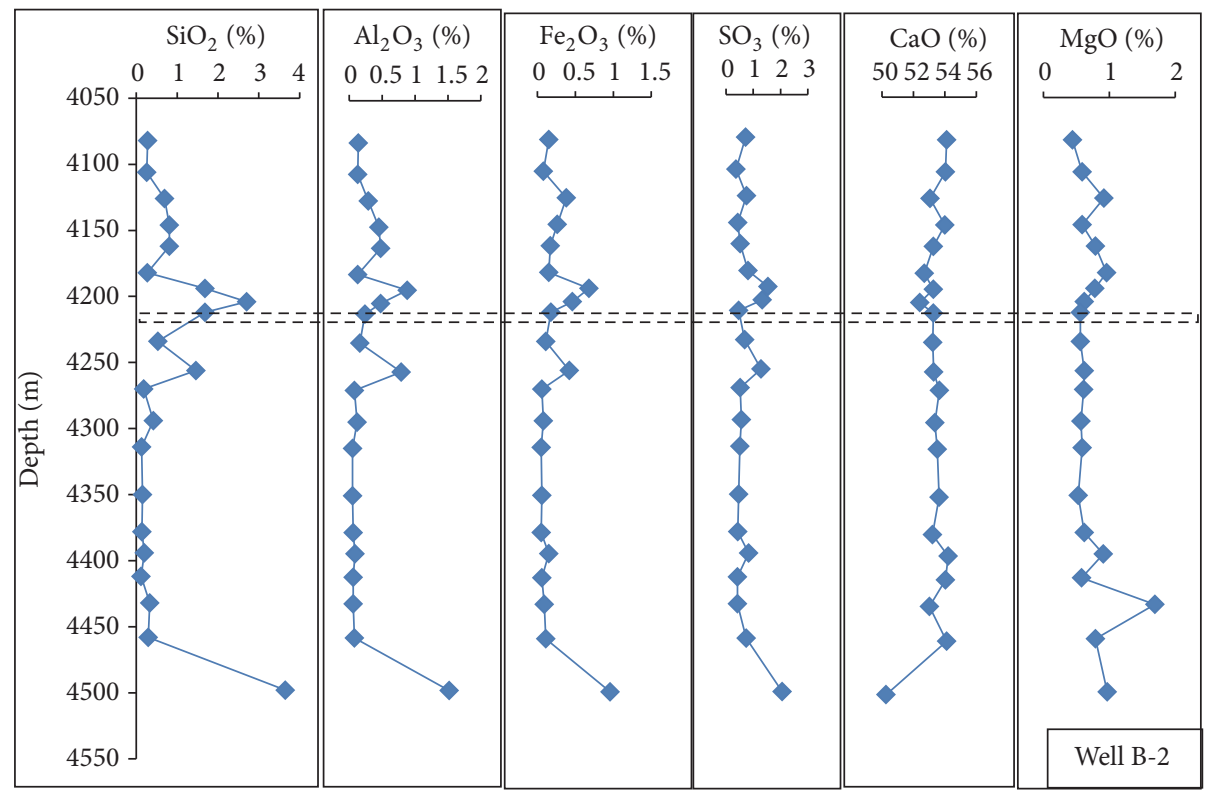

(a)

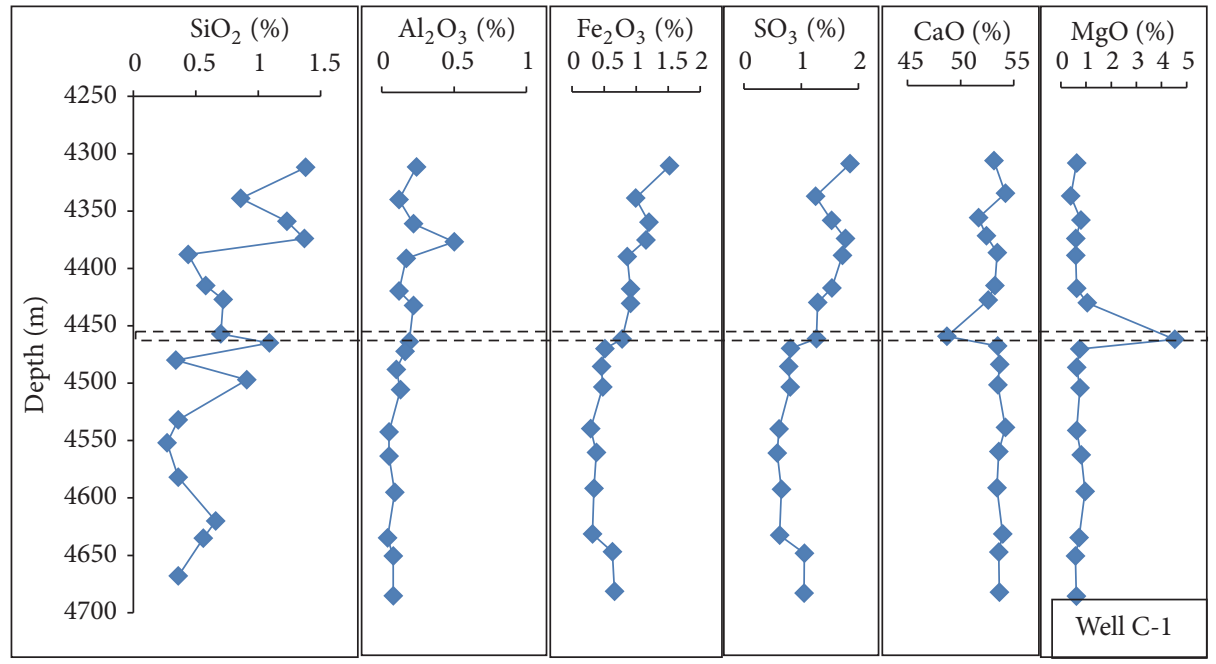

(b)

FIGURE 12: Chemical variation plots of selected major oxides showing depositional changes in the Lower Fahliyan Formation: (a) in well B-2 and (b) in well C-1 in different oil fields. Dashed lines are correlated to a differentiated horizon of two formation pore pressure systems (high and lower).

suggesting the lateral oil migration from Garau source rock to upper compartment of Lower Fahliyan reservoir.

Among the various mechanisms of generating overpressure state in the formation is, more possible, the dewatering of the Garau basinal sediments (as the time equivalent of the Fahliyan reservoir with an interfingering relationship) in a confined porosity system during burial, which could initially trigger the pore pressuring, which later could be amplified due to pore network compressibility during the rapid deposition of syntectonic Mio-Pliocene sedimentary succession.

Therefore, it seems there are several factors interfering in producing this abnormal pore pressure pattern in the Fahliyan Formation such as lateral variation and vertical facies changes to prevent the internal relation. The variations of major chemical elements in this formation are also reflected the vertical changes during deposition of upper part of Fahliyan Formation.

\section{Competing Interests}

The authors declare that they have no competing interests.

\section{Acknowledgments}

The authors would like to acknowledge the National Iranian Oil Company (NIOC) Exploration Directorate for permission to publish this paper and Research Manager of Shahid Chamran University of Ahvaz for their encouragements. 


\section{References}

[1] S. Morris, B. Vestal, K. O’Neill et al., “The pore pressure regime of the northern Gulf of Mexico: geostatistical estimation and regional controls," AAPG Bulletin, vol. 99, no. 1, pp. 91-118, 2015.

[2] A. A. Feyzullayev and I. Lerche, "Occurrence and nature of overpressure in the sedimentary section of the South Caspian Basin, Azerbaijan," Energy Exploration and Exploitation, vol. 27, no. 5, pp. 345-366, 2009.

[3] M. R. P. Tingay, C. K. Morley, A. Laird et al., "Evidence for overpressure generation by kerogen-to-gas maturation in the northern Malay Basin," AAPG Bulletin, vol. 97, no. 4, pp. 639-672, 2013.

[4] R. A. McTavish, "Pressure retardation of vitrinite diagenesis, offshore north-west Europe," Nature, vol. 271, no. 5646, pp. 648650, 1978 .

[5] R. A. McTavish, "The role of overpressure in the retardation of organic matter maturation," Journal of Petroleum Geology, vol. 21, no. 2, pp. 153-186, 1998.

[6] F. Hao, Y. Sun, S. Li, and Q. Zhang, "Overpressure retardation of organic-matter maturation and petroleum generation: a case study from the Yinggehai and Qiongdongnan Basins, South China Sea," AAPG Bulletin, vol. 79, no. 4, pp. 551-562, 1995.

[7] F. Hao, S. Li, Y. Sun, and Q. Zhang, "Characteristics and origin of the gas and condensate in the Yinggehai Basin, offshore South China Sea: evidence for effects of overpressure on petroleum generation and migration," Organic Geochemistry, vol. 24, no. 3, pp. 363-375, 1996.

[8] F. Hao, S. Li, W. Dong, Z. Hu, and B. Huang, "Abnormal organicmatter maturation in the Yinggehai Basin, South China Sea: implications for hydrocarbon expulsion and fluid migration from overpressured systems," Journal of Petroleum Geology, vol. 21, no. 4, pp. 427-444, 1998.

[9] A. D. Carr, "A vitrinite reflectance kinetic model incorporating overpressure retardation," Marine and Petroleum Geology, vol. 16, no. 4, pp. 355-377, 1999.

[10] J. C. Quick and D. E. Tabet, "Suppressed vitrinite reflectance in the Ferron coalbed gas fairway, central Utah: possible influence of overpressure," International Journal of Coal Geology, vol. 56, no. 1-2, pp. 49-67, 2003.

[11] R. C. Selley, Elements of Petroleum Geology, Elsevier, 1998.

[12] A. D. Carr, "Suppression and retardation of vitrinite reflectance, Part 1. Formation and significance for hydrocarbon generation," Journal of Petroleum Geology, vol. 23, no. 3, pp. 313-343, 2000.

[13] A. D. Carr, "Suppression and retardation of vitrinite reflectance, part 2. Derivation and testing of a kinetic model for suppression," Journal of Petroleum Geology, vol. 23, no. 4, pp. 475-496, 2000.

[14] J. M. Hunt, "Generation and migration of petroleum from abnormally pressured fluid compartments," American Association of Petroleum Geologists Bulletin, vol. 74, no. 1, pp. 1-12, 1990.

[15] B. E. Law and C. W. Spencer, Abnormal Pressure in Hydrocarbon Environments: AAPG Bulletin, v. Memoir 70, pp. 1-11, 1998.

[16] J. M. Hunt, J. K. Whelan, L. B. Eglinton, and L. M. Cathles, "Gas generation. A major cause of deep Gulf Coast overpressures," Oil and Gas Journal, vol. 92, no. 29, pp. 59-63, 1994.

[17] M. J. Osborne and R. E. Swarbrick, "Mechanisms for generating overpressure in sedimentary basins: a reevaluation," $A A P G$ Bulletin, vol. 81, no. 6, pp. 1023-1041, 1997.

[18] M. Webster, S. O'Connor, B. Pindar, and R. Swarbrick, "Overpressures in the Taranaki Basin: distribution, causes, and impli- cations for exploration," AAPG Bulletin, vol. 95, no. 3, pp. 339370, 2011

[19] F. Hao, S. Li, Z. Gong, and J. Yang, "Thermal regime, interreservoir compositional heterogeneities, and reservoir-filling history of the Dongfang gas field, Yinggehai basin, South China sea: evidence for episodic fluid injections in overpressured basins?" AAPG Bulletin, vol. 84, no. 5, pp. 607-626, 2000.

[20] X. Luo, W. Dong, J. Yang, and W. Yang, "Overpressuring mechanisms in the Yinggehai Basin, South China Sea," AAPG Bulletin, vol. 87, no. 4, pp. 629-645, 2003.

[21] B. Habibnia, A. Feghhi, and H. Amiri Bakhtiar, "Study of stratigraphy, biostratigraphy, microfacies, diagenesis, sequence stratigraphy and reservoir potential of the fahliyan formation in the marun oil field, Zagros Basin, Southwest Iran," in Proceedings of the 72nd EAGE Conference and Exhibition incorporating (SPE EUROPEC '10), June 2010.

[22] M. Jamalian, M. H. Adabi, M. R. Moussavi, A. Sadeghi, D. Baghbani, and B. Ariyafar, "Facies characteristic and paleoenvironmental reconstruction of the Fahliyan Formation, Lower Cretaceous, in the Kuh-e Siah area, Zagros Basin, southern Iran," Facies, vol. 57, no. 1, pp. 101-122, 2011.

[23] M. Khosravi, Y. Lasemi, and M. Feizi, "Platform to basin facies transition in the lower cretaceous fahliyan formation: evidence for the formation of garu intra," in Proceedings of the 1st International Petroleum Conference and Exhibition, European Association of Geoscientists and Engineers, EAGE, Shiraz, Iran, 2009.

[24] M. Sabouhi, D. Jahani, F. T. Qurayem, and A. Aminzadeh, "Depositional environment and sequence stratigraphy of the Neocomian Fahliyan Formation in the north Dezful Embayment, southwest Iran," in Proceedings of the 9th Middle East Geosciences Conference, pp. 26-28, April 2010.

[25] A. Shakeri and S. Parham, "Reservoir characterization and quality controlling factors of the fahliyan formation located in Southwest Iran," Journal of Sciences, Islamic Republic of Iran, vol. 24, no. 2, pp. 135-148, 2013.

[26] A. Abyat, D. Baghbani, M. Afghah, N. K. Ghadimvand, and A. Feghi, "Microbiostratigraphy and lithostratigraphy of Fahliyan and Gadvan Formations in Kuh-e-Surmeh (Zagros Basin, Southwest Iran)," Advances in Environmental Biology, vol. 6, no. 12, pp. 3078-3086, 2012.

[27] M. H. Adabi, M. A. Salehi, and A. Ghabeishavi, "Depositional environment, sequence stratigraphy and geochemistry of Lower Cretaceous carbonates (Fahliyan Formation), south-West Iran," Journal of Asian Earth Sciences, vol. 39, no. 3, pp. 148-160, 2010.

[28] S. Chatterjee, S. Basu, and A. Turki, "Yamama reservoir compartmentalization in majnoon: a preliminary perspective," in Proceedings of the 2nd EAGE Workshop on Iraq, September 2013.

[29] H. Motiei, Stratigraphy of Zagros: Geological Survey of Iran Tehran, 1993.

[30] M. R. Saadatinejad and K. Sarkarinejad, "Application of the spectral decomposition technique for characterizing reservoir extensional system in the Abadan Plain, southwestern Iran," Marine and Petroleum Geology, vol. 28, no. 6, pp. 1205-1217, 2011.

[31] J. K. Pitman, D. Steinshouer, and M. D. Lewan, "Petroleum generation and migration in the Mesopotamian Basin and Zagros fold belt of Iraq: results from a basin-modeling study," GeoArabia, vol. 9, no. 4, pp. 41-72, 2004.

[32] Q. Abeed, A. Alkhafaji, and R. Littke, "Source rock potential of the upper Jurassic-lower Cretaceous succession in the Southern Mesopotamian Basin, Southern Iraq," Journal of Petroleum Geology, vol. 34, no. 2, pp. 117-134, 2011. 
[33] I. Abdollahie Fard, A. Braathen, M. Mokhtari, and S. A. Alavi, "Interaction of the zagros fold-thrust belt and the arabian-type, deep-seated folds in the abadan plain and the dezful embayment, SW Iran ," Petroleum Geoscience, vol. 12, no. 4, pp. 347$362,2006$.

[34] M. Al-Husseini, "Origin of the Arabian Plate structures: amar collision and Najd Rift," GeoArabia, vol. 5, no. 4, pp. 527-542, 2000.

[35] Q. Abeed, D. Leythaeuser, and R. Littke, "Geochemistry, origin and correlation of crude oils in Lower Cretaceous sedimentary sequences of the southern Mesopotamian Basin, southern Iraq," Organic Geochemistry, vol. 46, pp. 113-126, 2012.

[36] G. A. James and J. G. Wynd, "Stratigraphic nomenclature of Iranian oil consortium agreement area," AAPG Bulletin, vol. 49, no. 12, pp. 2182-2245, 1965.

[37] P. R. Sharland, R. Archer, D. M. Casey et al., Arabian Plate Sequence Stratigraphy, vol. 2 of Special Publication, GeoArabia, 2001.

[38] R. B. Davies, D. M. Casey, A. D. Horbury, P. R. Sharland, and M. D. Simmons, "Early to mid-Cretaceous mixed carbonate-clastic shelfal systems: examples, issues and models from the Arabian Plate," GeoArabia, vol. 7, no. 3, pp. 541-598, 2002.

[39] F. N. Sadooni, "From Leeward Ramp to Block-faulted shelf: sequence stratigraphy and petroleum prospects of Cretaceous sediments of southern Iraq," GeoArabia, vol. 2, no. 4, pp. 476496, 1997.

[40] A. A. Al-Fares, M. Bouman, and P. Jeans, "A new look at the Middle to Lower Cretaceous stratigraphy, offshore Kuwait," GeoArabia, vol. 3, no. 4, pp. 543-560, 1998.

[41] J. M. Hunt, Petroleum Geochemistry and Geology, W.H. Freeman and Company, 1995.

[42] F. Hao, W. Zhu, H. Zou, and P. Li, "Factors controlling petroleum accumulation and leakage in overpressured reservoirs," AAPG Bulletin, vol. 99, no. 5, pp. 831-858, 2015.

[43] V. Atashbari and M. R. Tingay, "Pore pressure prediction in carbonate reservoirs," in Proceedings of the SPE Latin America and Caribbean Petroleum Engineering Conference, Mexico City, Mexico, April 2012.

[44] P. Japsen, "Regional velocity-depth anomalies, North Sea Chalk: a record of overpressure and Neogene uplift and erosion," $A A P G$ Bulletin, vol. 82, no. 11, pp. 2031-2074, 1998.

[45] O. V. Vejbæk, "Disequilibrium compaction as the cause for cretaceous-paleogene overpressures in the Danish North Sea," AAPG Bulletin, vol. 92, no. 2, pp. 165-180, 2008.

[46] B. Alizadeh, H. Saadati, M. Rashidi, and M. Kobraei, "Geochemical investigation of oils from Cretaceous to Eocene sedimentary sequences of the Abadan Plain, Southwest Iran," Marine and Petroleum Geology, vol. 73, pp. 609-619, 2016. 

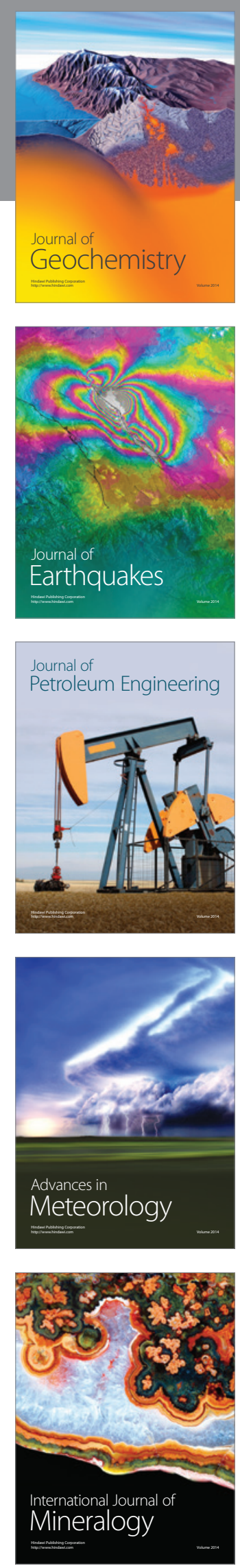
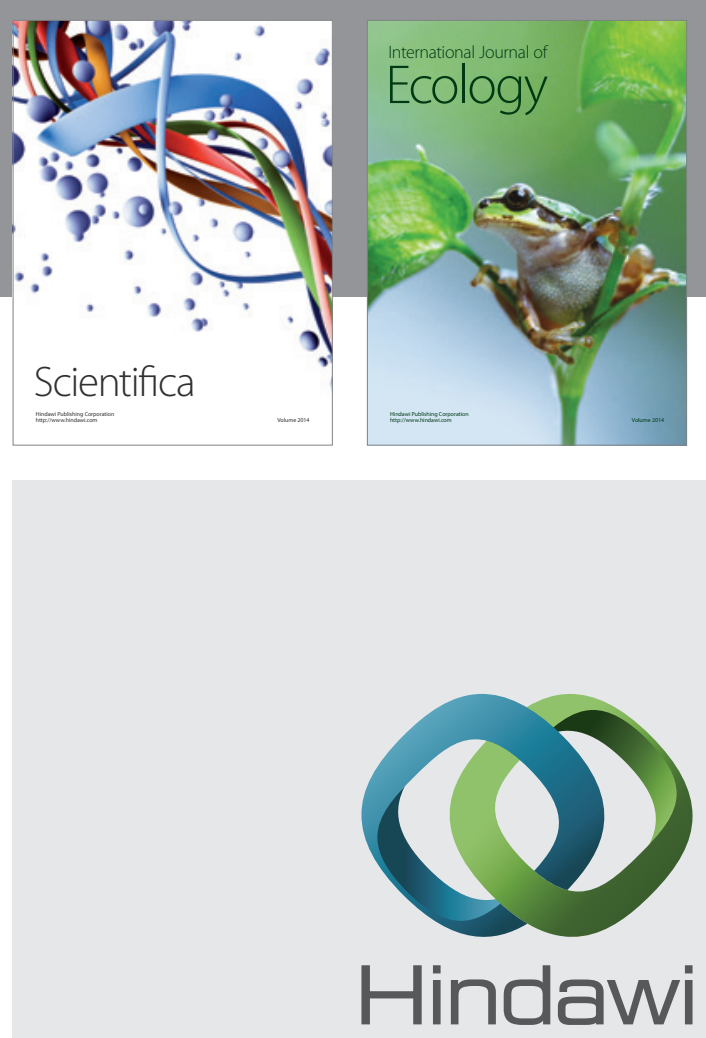

Submit your manuscripts at

https://www.hindawi.com
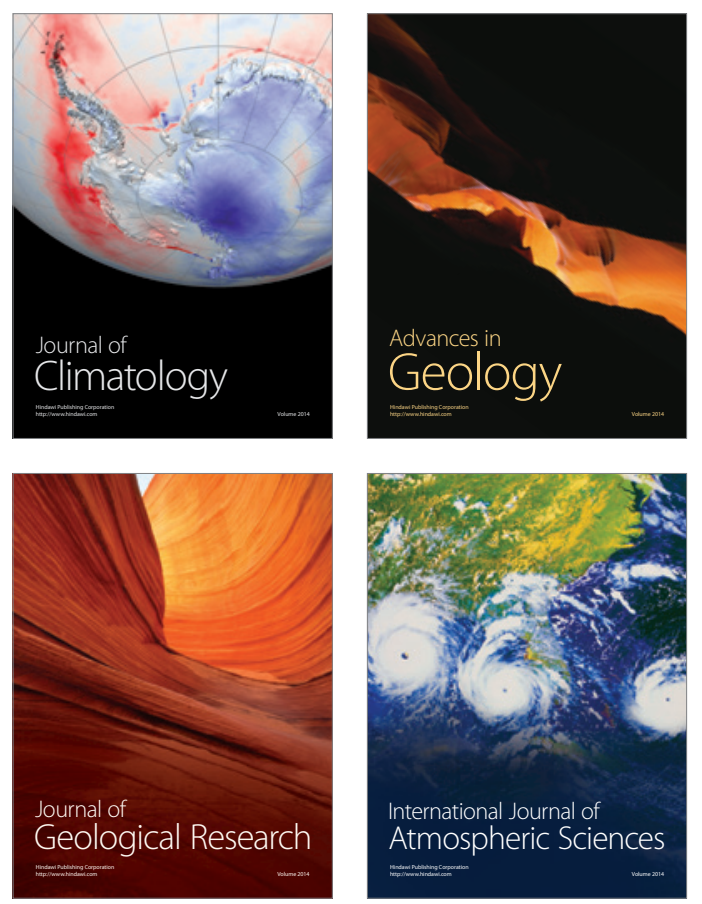

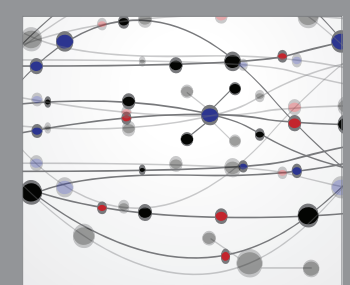

The Scientific

\section{World Journal}
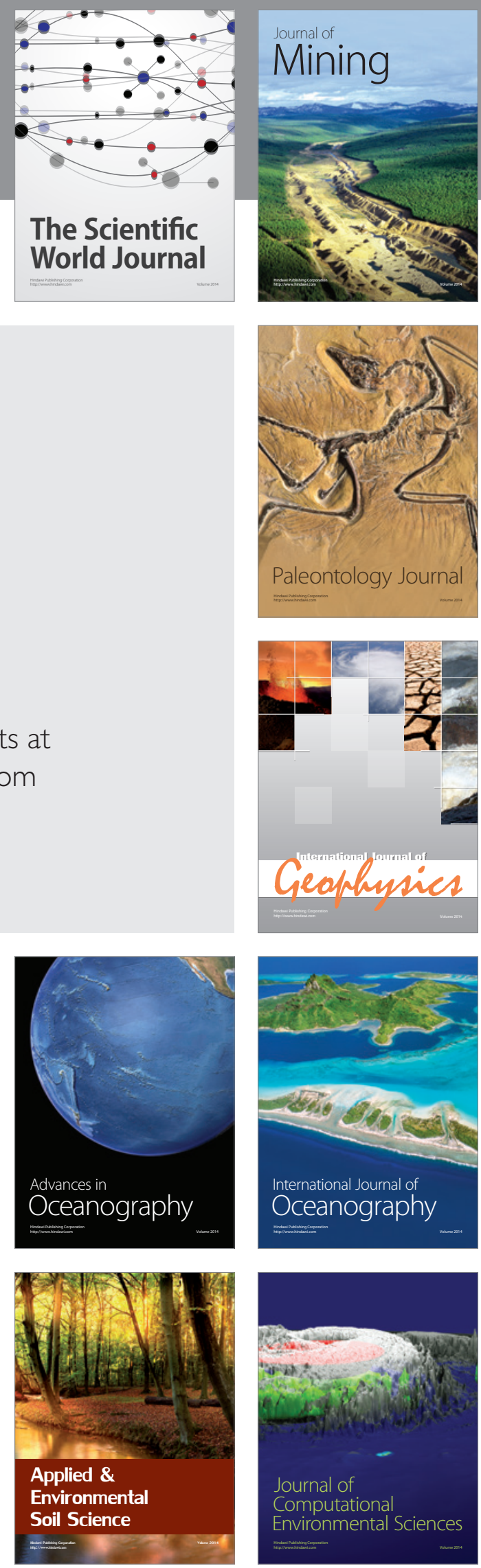